\title{
Светорегуляция и электрофоретическая подвижность изоформ НАДФ-изоцитратдегидрогеназы в листьях кукурузы
}

\author{
(C) 2020 Гродецкая T.А., Шестаков Р.А., Епринцев А.Т. \\ Воронежский государственный университет, Воронеж
}

Поступила в редакцию 14.10 .2020 г.

DOI: $10.17308 /$ sorpchrom.2020.20/3055

Свет является важнейшим регулятором процесса фотосинтеза, и также тесно связанного с ним цикла Кребса. Световая регуляция установлена для многих ферментов, в том числе, цикла трикарбоновых кислот, и в данном процессе может быть задействована фитохромная система. НАДФизоцитратдегидрогеназы высших растений (НАДФ-ИДГ, КФ 1.1.1.42) представляют собой комплекс ферментов, локализованных в цитозоле, митохондриях, хлоропластах и пероксисомах и могут участвовать в процессе адаптации растения к смене светового режима. Данная работа посвящена исследованию изоцитратдегидрогеназной системы в условиях смены светового режима в листьях кукурузы. Активность фермента измерялась спектрофотометрически, проводилось дифференциальное центрифугирование для изучения субклеточной локализации. Изоферментный состав определялся на основе изучения электрофоретической подвижности методом электрофореза в ПААГ. Исследовалось влияние фитохромной системы на активность цитозольной, хлоропластной, митохондриальной изоформ НАДФ-ИДГ путем моделирования воздействия света разной длины волны на растения кукурузы. Установлена зависимость активности НАДФ-ИДГ из листьев кукурузы от стадии прорастания. Пик активности цитозольной формы наблюдается на пятый день прорастания, митохондриальной формы на четвертый день, а хлоропластной - на восьмой день прорастания семян кукурузы. Установлено, что дифференциальная активность изоформ НАДФ-ИДГ в листьях кукурузы в процессе развития обусловлена их различной функцией в клетке растения. В работе показана субклеточная локализация НАДФ-ИДГ и определена активность в субклеточных фракциях. Выявлено, что доминирующая активность присутствует в цитозоле, составляя $72 \%$ от общей активности. На основе результатов исследования световой регуляции изоформ НАДФ-ИДГ выявлено увеличение активности цитозольной и хлоропластной форм в листьях кукурузы при воздействии красного света с длиной волны 660 нм, в то время как для митохондриальной формы наблюдалось снижение активности при воздействии КС. Облучение дальним красным светом (730 нм) снимало наблюдаемый эффект для обоих изоформ. Полученные результаты свидетельствуют об участии фитохромной системы в регуляции активности цитозольной, хлоропластной и митохондриальной изоформ НАДФ-ИДГ в листьях кукурузы при смене светового режима.

Ключевые слова: изоцитратдегидрогеназа, активность, изоформы, фитохромная регуляция, кукуруза.

\section{Введение}

НАДФ-изоцитратдегидрогеназа (НАДФ-ИДГ, КФ 1.1.1.42) осуществляет превращение изоцитрата в 2-оксоглутарат с одновременным восстановлением НАД ${ }^{+}$ до НАДФН. НАДФ-ИДГ локализована в митохондриях, хлоропластах, цитоплазме и пероксисомах у многих высших растений [1-3]. Тем не менее, роль каждой изоформы до сих пор подробно не изучена. Роль цитозольной формы НАДФ-ИДГ, предположительно, заключается в поставке 2-оксоглутарата для работы хлоропластной глу- 
таматсинтазной ферментной системы. Митохондриальная форма НАДФ-ИДГ выполняет поставку НАДФН для восстановления глутатиона. Точкой пересечения метаболической регуляции является взаимосвязь между фотосинтезом, фотодыханием и митохондриальным дыханием в зеленых листьях растений. Ранее было показано, что фитохромная система принимает участие в регуляции этих процессов. Фитохромная система регулирует работу некоторых ферментов цикла Кребса [4-7].

Ранее электрофоретическое исследование цитозольной и митохондриальной изоформ из листьев гороха показало, что более высокой электрофоретической подвижностью обладает митохондриальная форма [8]. Было также выявлено, что хлоропластная форма ИДГ из листьев табака обладает меньшим Rf (большей подвижностью) по сравнению с цитозольной формой НАДФ-ИДГ, поскольку обладает большим суммарным отрицательным зарядом [2].

Цель работы - исследовать влияние светового режима на функционирование НАДФ-ИДГ в листьях кукурузы с использованием метода электрофоретической подвижности.

\section{Эксперимент}

Объектом исследования являлись зеленые листья кукурузы (Zea mays L.), выращенной гидропонным методом при 16 часовом световом дне с интенсивностью света 25 Ватт $/ \mathrm{M}^{2}$.

Активность ИДГ определяли на спектрофотометре СФ-2000 (ОКБ Спектр, Россия) по изменению оптической плотности при восстановлении НАДФ до НАДФН при длине волны 340 нм [8]. Реакционная среда содержала: $2.5 \mathrm{~cm}^{3} 100 \mathrm{mM}$ Tris-HCl буфера ( $\mathrm{pH} 7.8$ ), 2 мМ MgCl 2,200 мкл 1.4 мМ НАДФ, 200 мкл 8.8 мМ изоцитрат натрия и 100 мкл пробы.

Субклеточную локализацию изучали методом дифференциального центрифугирования с последующим проведением электрофореза в ПААГ. Предварительно замороженные и измельчённые листья гомогенизировали при низкой температуре с помощью ступки и пестика в среде выделения, содержащей $100 \mathrm{MM}$ TrisHCl, $\mathrm{pH}=7.8$; 0.1 мМ ЭДТА, 1 мМ $\mathrm{MgCl}_{2}, 2$ мМ ДТТ, 250 мМ сахарозу, в соотношении проба : среда выделения $=1: 4$. Гомогенат фильтровали через капрон, затем центрифугировали 5 минут при 3000 об/мин. Осадок, содержащий хлоропласты, ресуспендировали в 200 мкл среды, содержащей $100 \mathrm{мM}$ TrisHCl, pH=7.8; 0.1 мМ ЭДТА, 1 мM MgCl , 2 мМ ДТТ и $0.1 \%$ Тритон х100; затем центрифугировали 3 мин при 11000 об/мин и использовали супернатант для исследования хлоропластной формы ИДГ. Надосадок центрифугировали 15 минут при 11000 об/мин для осаждения митохондрий. Полученный супернатант использовали для исследования цитозольной формы ИДГ. Осадок ресуспендировали в среде, состав которой описан выше, центрифугировали пробу для осаждения остатков мембран и надосадок использовали для измерения активности ИДГ и проведения электрофореза.

Изоферментный состав определяли методом электрофореза в ПААГ. Концентрация верхнего геля составляла 4\%, в соотношении акриламид-бисакриламид (AА/БАA) 30:1 в 125 мМ Tris-HCl (pH 6.8), а нижнего геля - 7\%, в соотношении AA/БАА (30:1) в 375 мМ Tris-HCl (pH 8.8). Электродный буфер содержал Tris-HCl (25MM) и глицин (192 мМ). Специфическое окрашивание проводили в среде, содержащей 100 мМ Tris- $\mathrm{HCl}$ pH 7.8; 3.87 мМ изоцитрат, 50 мМ $\mathrm{MgCl}_{2}, 0.13$ мМ НАДФ, 1.2 мМ нитросиний тетразолий и 3.26 мМ феназинметасульфат. Реакцию останавливали, добавляя в среду проявления 7\% уксусную кислоту. 
Для изучения влияния фитохромной системы на активность изоферментов НАДФ-ИДГ растения кукурузы помещали в темноту на 24 ч. Далее первую группу растений кукурузы облучали красным светом (660 нм) с использованием светодиодов КИПД40М40-К-П6 (Россия) в течение 15 минут, вторую группу облучали дальним красным светом (730 нм) с использованием светодиодов 3Л127А-5 (Россия). Третья группа растений была последовательно облучена красным светом (15 минут), затем дальним красным светом (15 минут). Далее пробы инкубировали в течение 3 часов в темноте и использовали для определения активности фермента ИДГ.

\section{Обсуждение результатов}

Динамика активности различных форм НАДФ-изоцитратдегидрогеназы была изучена при прорастании семян кукурузы. Установлено, что максимум активности для цитозольной формы наблюдается на 5 день прорастания, для хлоропластной формы на 4 день, а для митохондриальной - на 8 день развития семян (рис. 1).

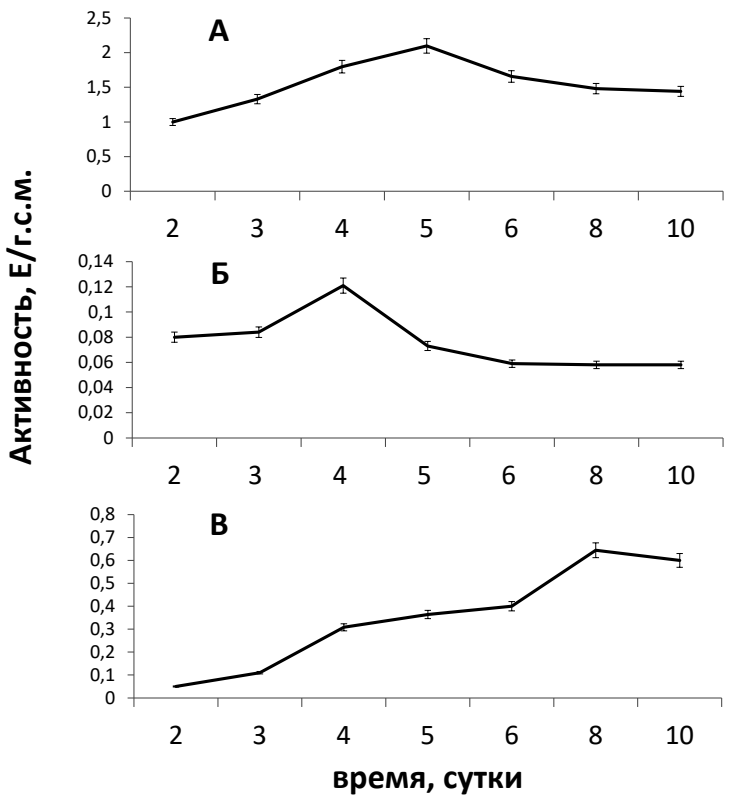

Рис. 1. Динамика активности изоформ НАДФ-ИДГ из листьев кукурузы при прорастании: А - цитозольная форма, Б - митохондриальная форма, В - хлоропластная форма.

Fig. 1. Dynamics of activity of NADP-IDH isoforms from maize leaves during germination: A - cytosolic isoform, $\mathrm{B}$ - mitochondrial isoform, $\mathrm{C}$ - chloroplast isoform.

Для исследования активности каждой из изоформ НАДФ-ИДГ провели изоплотностное центрифугирование в градиенте плотности сахарозы. Полученные фракции исследовали с помощью электрофореза. Специфическое проявление позволило показать наличие трех форм исследуемого фермента с различной электрофоретической подвижностью. Так, для цитозольной фракции $\mathrm{Rf}$ составляла 0.33 , для митохондриальной -0.28 , для хлоропластной -0.30 (рис. 2).

Определение активности во фракциях исследуемого фермента показало, что цитозольная форма доминирует в зеленых листьях кукурузы, составляя $72 \%$ от общей активности НАДФ-ИДГ. Активность ИДГ в хлоропластах равнялась $20 \%$, а в митохондриях - 8\% от обшей активности исследуемого фермента. 


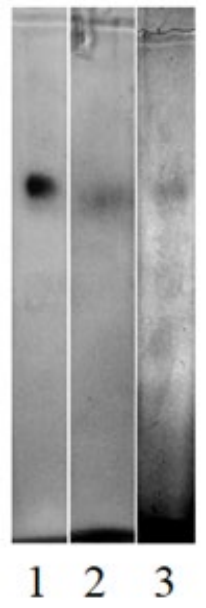

a

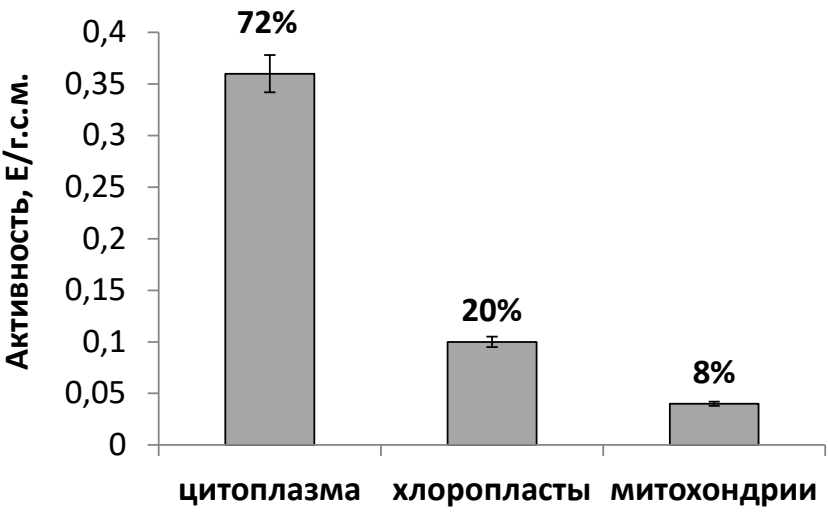

б

Рис. 2. Электрофореграмма различных субклеточных фракций НАДФ-ИДГ и величина ферментативной активности: а: 1 - цитоплазматическая ИДГ, $\mathrm{Rf}=0.33$

2 - митохондриальная ИДГ, $\mathrm{Rf}=0.28 ; 3$ - хлоропластная ИДГ, $\mathrm{Rf}=0.30$; б - активность ИДГ в субклеточных фракциях

Fig. 2. Electropherogram of various subcellular fractions of NADP-IDH and the enzymatic activity: a: 1 - cytoplasmic IDH, $\mathrm{Rf}=0.33 ; 2-$ mitochondrial IDH, $\mathrm{Rf}=0.28 ; 3-$ chloroplast IDH, $\mathrm{Rf}=0.30 ;$ и $-\mathrm{IDH}$ activity in subcellular fractions

Для определения доли активности каждого из исследуемых изоферментов НАДФ-ИДГ при прорастании семян кукурузы был проведен электрофорез в ПААГ гомогената из проростков кукурузы на 3, 4, 5 и 6 дни прорастания. При специфическом проявлении были детектированы две формы НАДФ-ИДГ с $\mathrm{Rf}=0.33$ и $\mathrm{Rf}=0.30$, что соответствует цитозольной и хлоропластной формам исследуемого фермента (рис. 3).

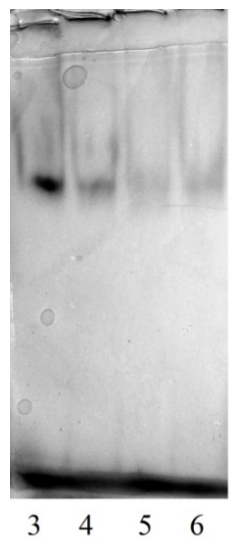

Рис. 3. Электрофореграмма изоферментов НАДФ-ИДГ при прорастании кукурузы (3, 4, 5, 6 дни).

Fig. 3. Electropherogram of NADP-IDH isozymes during maize germination $(3,4,5,6$ days $)$.

Увеличение концентрации хлоропластной изоформы фермента свидетельствует о его важной роли при развитии процессов фотосинтеза в зеленом листе кукурузы. Отсутствие на электрофореграмме митохондриальной формы НАДФ-ИДГ при специфическом проявлении из гомогената листьев кукурузы может быть связано с небольшим количеством данной формы в грубых экстрактах. 
Исследование участия фитохромной системы в регуляции различных форм НАДФ-ИДГ осуществлялось путем моделирования условий освещения растений кукурузы. Установлено, что воздействие КС увеличивает активность цитозольной (рис. 4) и хлоропластной (рис. 5) форм НАДФ-ИДГ относительно вариантов, выдержанных в темноте. Для митохондриальной формы наблюдалось снижение активности в условиях воздействия КС (рис. 6). При воздействии ДКС на различные изоформы НАДФ-ИДГ не наблюдалось изменений в активности цитозольной, митохондриальной и хлоропластной изоформ НАДФ-ИДГ относительно растений, инкубируемых в темноте. Активность в листьях, облученных последовательно КС, затем ДКС, была на уровне варианта «темнота» и «ДКС». Полученные результаты свидетельствуют об участии фитохромной системы в регуляции цитозольной, хлоропластной и митохондриальной изоформ НАДФ-ИДГ.

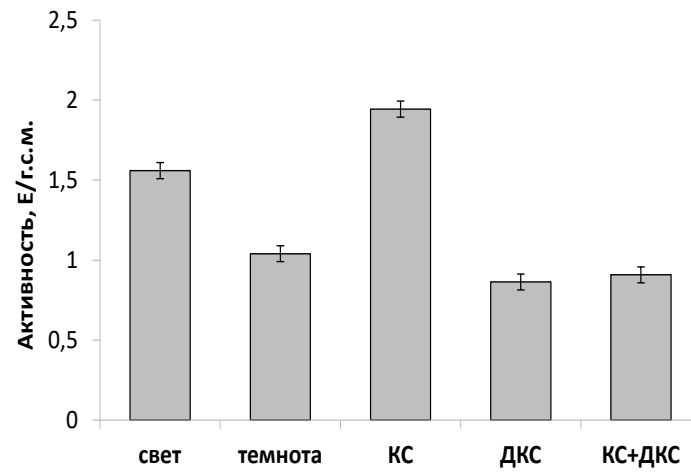

Рис. 4. Активность цитозольной НАДФ-ИДГ в различных условиях освещения. Свет - растения, освещенные полным спектром, темнота растения, инкубированные без воздействия света, КС - растения, освещенные красным светом, ДКС - растения, облученные дальним красным светом, КС+ДКС - растения, последовательно облученные красным, затем дальним красным светом.

Fig. 4. Cytosolic NADP-IDH activity under various lighting conditions. Light plants were illuminated with the full spectrum, darkness - plants were incubated without exposure to light, RL - plants were illuminated with red light, FRL - plants were illuminated with far red light, RL + FRL - plants were successively illuminated with red, then far red light

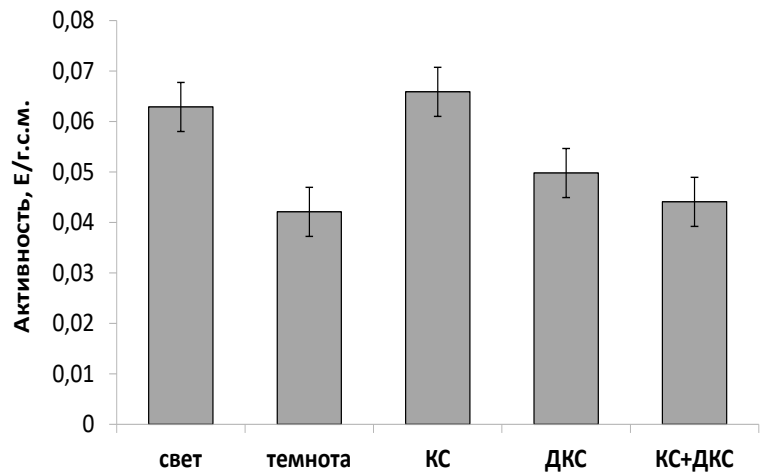

Рис. 5. Активность хлоропластной НАДФ-ИДГ в различных условиях освещения. Свет - растения, освещенные полным спектром, темнота - растения, инкубированные без воздействия света, КС - растения, освещенные красным светом, ДКС - растения, облученные дальним красным светом, КС+ДКС - растения, последовательно облученные красным, затем дальним красным светом.

Fig. 5. Chloroplast NADP-IDH activity under various lighting conditions. Light plants were illuminated with the full spectrum, darkness - plants were incubated without exposure to light, RL - plants were illuminated with red light, FRL - plants were illuminated with far red light, RL + FRL plants were successively illuminated with red, then far red light 


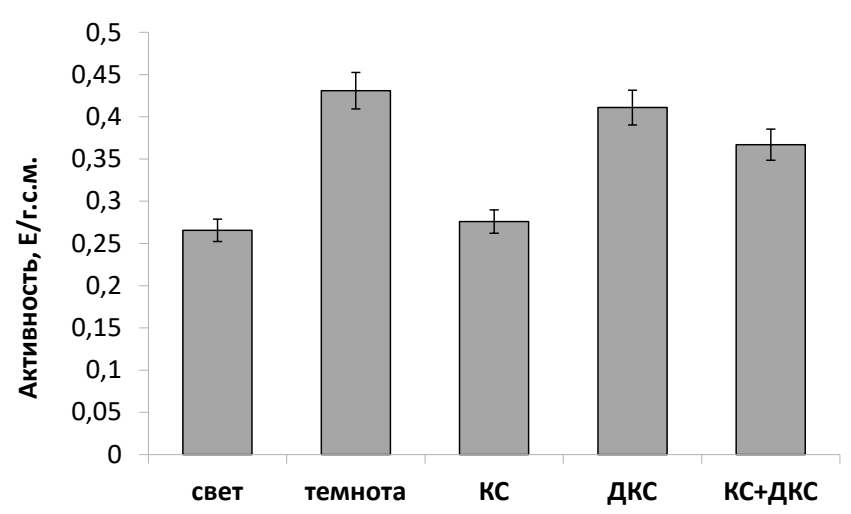

Рис. 6. Активность митохондриальной НАДФ-ИДГ в различных условиях освещения. Свет - растения, освещенные полным спектром, темнота - растения, инкубированные без воздействия света, КС - растения, освещенные красным светом, ДКС - растения, облученные дальним красным светом, КС+ДКС - растения, после-

довательно облученные красным, затем дальним красным светом.

Fig. 6. Mitochondrial NADP-IDH activity under various lighting conditions. Light plants were illuminated with the full spectrum, darkness - plants were incubated without exposure to light, RL - plants were illuminated with red light, FRL - plants were illuminated with far red light, RL + FRL - plants were successively illuminated with red, then far red light.

\section{Заключение}

В ходе проведенного исследования установлена зависимость активности НАДФ-ИДГ из листьев кукурузы от стадии прорастания. Выявлено, что активность цитозольной формы наблюдается на пятый день прорастания, в то время как митохондриальной - на четвертый день, а хлоропластной на восьмой день развития семян кукурузы, что свидетельствует о различной роли каждой из изоформ в клетке растения. Увеличение активности хлоропластной формы к восьмому дню развития может быть связано с активизацией процессов фотосинтеза и снижением роли цикла Кребса в качестве поставщика энергии и субстратов для синтетических процессов. Определение субклеточной локализации показало доминирующее содержание цитозольной формы НАДФ-ИДГ в клетках кукурузы, в то время как митохондриальная форма составляет лишь 8\% общей активности. Исследование световой регуляции НАДФ-ИДГ выявило, что активность цитозольной и хлоропластной форм НАДФИДГ была значительно выше на свету по сравнению с растениями, выдержанными в темноте, что может связывать их функционирование с процессом фотосинтеза. При этом, воздействие КС также увеличивало активность данных изоформ, а действие ДКС снимало эффект, полученный от воздействия красного света, что свидетельствует об участии фитохромной системы в регуляции цитозольной и хлоропластной форм фермента. Фитохромная регуляция была также выявлена для митохондриальной формы НАДФ-ИДГ, но воздействие КС и ДКС, напротив, снижало активность данной формы относительно контрольных вариантов, инкубированных в темноте.

Таким образом, проведенное исследование свидетельствует о функционировании сложной изоцитратдегидрогеназной системы в клетках кукурузы, которая играет важную роль в процессе прорастания и регулируется воздействием света, где основную роль может играть фитохромная система. 


\title{
Список литературы
}

1. Hodges M. Flesch V., Gálvez S., Bismuth E. // Plant Physiology and Biochemistry. 2003. Vol. 41. pp. 577-585.

2. Gálvez S., Bismuth E., Sarda C., Gadal P.// Plant Physiology. 1994. Vol. 105. pp. 593-600.

3. Eprintsev A.T., Fedorin D.N., Nikitina M.V., Igamberdiev A.U. // Journal of plant physiology. 2015. Vol. 181. pp. 14-19.

4. Popov V.N., Eprintsev A.T., Fedorin D.N., Igamberdiev A.U. // FEBS letters. 2010. Vol. 584. pp. 199-202.

5. Rockwell N.C., Su Y.S., Lagarias J.C. // Annu. Rev. Plant Biol. 2006. Vol. 57. pp. 837858.
6. Eprintsev A.T., Fedorin D.N., Sazonova O.V., Igamberdiev A.U. // Plant Physiology and Biochemistry. 2016. Vol. 102. pp. 161-166.

7. Popov V.N., Fedorin D.N., Eprintsev A.T. // Russian Journal of Plant Physiology. 2007. Vol. 54. pp. 360-365.

8. Igamberdiev A.U., Gardeström P. // Biochimica et Biophysica Acta (BBA)Bioenergetics. 2003. Vol. 1606. pp. 117-125.

9. Rasmusson A.G., Møller I.M. // Plant physiology. 1990. Vol. 94. pp. 1012-1018.

\section{Light regulation of NADP-isocitrate dehydrogenase isoforms functioning in maize leaves}

\author{
(C) 2020 Grodetskaia T.A., Shestakov R.A., Eprintsev A.T.
}

\author{
Voronezh State University, Voronezh, Russian Federation
}

Light is the most important regulator of the process of photosynthesis, and the Krebs cycle closely related to it. Light regulation has been established for many enzymes, including the enzymes of the tricarboxylic acid cycle, the phytochrome system also can be involved in the process of light regulation. NADPisocitrate dehydrogenases of higher plants (NADP-ICDH, EC 1.1.1.42) are a complex of enzymes localized in the cytosol, mitochondria, chloroplasts, and peroxisomes, which can be involved in the adaptation of plants to a change in light regime. This study is devoted to the investigation of the isocitrate dehydrogenase system under conditions of changing light regime in maize leaves. The enzyme activity was measured spectrophotometrically; differential centrifugation was used for the investigation of subcellular localization. The isozyme composition was determined by PAGE. The effect of the phytochrome system on the activity of the cytosolic, chloroplast, and mitochondrial isoforms of NADP-IDH was studied by modelling the effect of light of different wavelengths on maize plants. The dependence of the activity of NADP-ICDH from maize leaves during the germination stage was established. The peak of activity of the cytosolic form was observed on the fifth day of germination, while the peak of activity of the mitochondrial form was observed on the fourth day, and the chloroplast isoform had maximal activity on the eighth day of germination of maize seeds. It was shown the differential activity of NADP-ICDH isoforms in maize leaves during development was due to their different functions in the plant cell. Subcellular localization of NADP-IDH was demonstrated and the activity in subcellular fractions was determined. It was revealed that the dominant activity is present in the cytosol, accounting for $72 \%$ of the total activity. The light regulation of NADP-ICDH isoforms was investigated. An increase in the activity of the cytosolic and chloroplast isoforms in maize leaves was revealed under red light with a wavelength of $660 \mathrm{~nm}(\mathrm{RL})$, while for the mitochondrial isoform, a decrease in activity was observed under RL. Irradiation with far red light, $730 \mathrm{~nm}$ (FRL), removed this effect for both isoforms. The obtained results indicate the involvement of the phytochrome system in the regulation of the activity of the cytosolic, chloroplast, and mitochondrial isoforms of NADP-ICDH in maize leaves under the changed light pattern.

Keywords: isocitrate dehydrogenase, activity, isoforms, phytochrome system, maize

\section{References}

1. Hodges M. Flesch V., Gálvez S., Bismuth E., Plant Physiology and Biochemistry, 2003, Vol. 41, pp. 577-585.
2. Gálvez S., Bismuth E., Sarda C., Gadal P., Plant Physiology, 1994, Vol. 105, pp. 593-600. 
3. Eprintsev A.T., Fedorin D.N., Nikitina M.V., Igamberdiev A.U., Journal of plant physiology, 2015, Vol. 181, pp. 14-19.

4. Popov V.N., Eprintsev A.T., Fedorin D.N., Igamberdiev A.U., FEBS letters, 2010, Vol. 584, pp. 199-202.

5. Rockwell N.C., Su Y.S., Lagarias J.C., Annu. Rev. Plant Biol., 2006, Vol. 57, pp. 837-858.

6. Eprintsev A.T., Fedorin D.N., Sazonova O.V., Igamberdiev A.U., Plant Physiology and Biochemistry, 2016, Vol. 102, pp. 161-166.

Гродецкая Татьяна Александровна - аспирант, кафедра биохимии и физиологии клетки, Воронежский государственный университет, Воронеж

Шестаков Роман Анатольевич - студент, кафедра биохимии и физиологии клетки, Воронежский государственный университет, Воронеж

Епринцев Александр Трофимович - д.б.н., проф., кафедра биохимии и физиологии клетки, Воронежский государственный университет, Воронеж
7. Popov V.N., Fedorin D.N., Eprintsev A.T., Russian Journal of Plant Physiology, 2007, Vol. 54, pp. 360-365.

8. Igamberdiev A.U., Gardeström P., Biochimica et Biophysica Acta (BBA)Bioenergetics, 2003, Vol. 1606, pp. 117-125.

9. Rasmusson A.G., Møller I.M., Plant physiology, 1990, Vol. 94, pp. 1012-1018.

Grodetskaia Tatiana A. - Postgraduate Student, Department of Biochemistry and Physiology, Voronezh State University, Voronezh, e-mail: tatyana.pokusina@yandex.ru

Shestakov Roman A. - student, Department of Biochemistry and Physiology, Voronezh State University, Voronezh, e-mail: sofer82@mail.ru

Eprintsev Alexander T. - Doctor of Biology, Professor, Department of Biochemistry and Physiology, Voronezh State University, Voronezh, email: bc366@bio.vsu.ru 